\title{
PENINGKATAN PENGETAHUAN, SIKAP, DAN TINDAKAN IBU TENTANG KANDUNGAN IODIUM DALAM GARAM KONSUMSI RUMAH TANGGA PADA DAERAH PESISIR DAN PEGUNUNGAN (Increased knowledge, attitudes, and actions of mothers about iodine content in household consumption salt in coastal and highlands areas)
}

\author{
Ampera Miko ${ }^{1^{*}}$ \\ ${ }^{1}$ Jurusan Gizi Politeknik Kesehatan Kemenkes Aceh, Jl. Soekarno Hatta, Kampus Terpadu Poltekkes Kemenkes Aceh RI \\ Aceh Lampeneurut, Aceh Besar. Indonesia \\ Email : checoks@yahoo.com
}

\begin{abstract}
ABSTRAK
Provinsi Aceh tahun 2013 mempunyai cakupan penggunaan garam yodium dalam rumah tangga sebesar 45,7\%, dan sedikit meningkat tahun 2015 sebesar 57,9\%. Rendahnya penggunaan garam beryodium merupakan faktor rendahnya pengetahuan dan perilaku yang tidak sesuai menurut pedoman gizi. Pelatihan dapat meningkatkan peran ibu dalam perilaku konsumsi garam beryodium. Penelitian bertujuan untuk meningkatkan pengetahuan, sikap, dan tindakan ibu tentang kandungan iodium dalam garam konsumsi rumah tangga melalui pelatihan. Desain penelitian yaitu quasi-eksperimen, dilakukan didaerah pesisir dan daerah pegunungan di Kecamatan Lhoknga, tahun 2018. Sampel yaitu ibu rumah tangga diambil secara random yaitu 54 orang. Pelatihan menggunakan metode praktik dan ceramah diskusi, serta wawancara untuk mengumpulkan data. Analisis statistik menggunakan Uji Repeated Measerud Anova dan Independent T-test. Hasil, pelatihan garam beryodium dapat meningkatkan pengetahuan, sikap dan tindakan ( $p<$ 0,01), pada kelompok ceramah, pengetahuan hanya dapat ditingkatkan sampai dengan minggu kedua $(p<0,01)$ dan pada minggu ketiga tidak menunjukan perbedaan ( $p>$ 0,05), tindakan ibu-ibu belum bisa ditingkatkan pada minggu pertama ( $p>0,05)$, dan signifikan peningkatannya minggu kedua dan ketiga ( $p<0,01)$. Pelatihan pemeriksaan garam beryodium mempunyai efektifitas yang lebih baik ( $p<0,01)$ dalam meningkatkan pengetahuan, sikap dan tindakan. Kesimpulan, pelatihan garam beryodium sangat baik dalam meningkatkan pengetahuan, sikap dan tindakan dibandingkan intervensi ceramah. Saran, perlu pemantauan dan pengawasan pemerintah melalui dinas kesehatan kabupaten terkait klaim pada kemasan garam beryodium yang mencantumkan garam dengan kadar yodium $\geq 30$ ppm.
\end{abstract}

Kata kunci: Garam yodium, pelatihan, pengetahuan, sikap, tindakan

${ }^{*}$ Penulis untuk korespondensi: checoks@yahoo.com

\begin{abstract}
Aceh Province in 2013 had 45,7\% use of iodized salt in households, and slightly increased in 2015 by 57,9\%. The low use of iodized salt is a factor in the lack of knowledge and behavior that is not in accordance with nutritional guidelines. Increasing iodized salt consumption is possible through the role of housewives through providing basic training. The research aims to increased mothers' knowledge, attitudes and actions about iodine content in household consumption salt through training. The research design is quasi-experiment, was conducted in coastal areas and highlands areas in Lhoknga District, at 2018, and samples were housewives as many as 54 people. The training uses practical methods and discussion, and interviews to collect data. Statistical analysis using the Repeated Measerud Anova and T-Independent. Results, iodized salt training can improve knowledge, attitude and practice $(p<0,01)$. Training examination of iodized salt has a better effectiveness $(p<0,01)$ compared to a discussion. In conclusion, intervention through training and discussion on iodized salt in housewives can significantly improve knowledge, attitudes and actions. Suggestions, it is necessary to monitor and supervise by the government through the district health office related to claims on iodized salt packaging that include salt with iodine levels $\geq 30$ ppm.
\end{abstract}

Keywords: Iodine salt, the training, knowledge, attitudes, actions

\section{PENDAHULUAN}

Strategi jangka Panjang yang dilakukan secara berkesinambungan adalah melakukan fortifikasi garam dengan yodium yang dikenal sebagai iodisasi garam. Penambahan yodium pada semua garam konsumsi telah disepakati 
sebagai cara yang aman, efektif, serta berkesinambungan untuk mencapai konsumsi yodium yang optimal bagi semua rumah tangga dan masyarakat. ${ }^{1} \quad$ United Nations General Assembly (UNGASS) telah menyepakati pembaharuan komitmen World Summit for Children yaitu pencapaian eliminasi gangguan akibat kekurangan yodium (GAKY) dan universal salt iodization (USI) atau garam beryodium untuk semua berupa konsumsi garam beryodium $90 \%$ secara berkesinambungan. Sementara itu, target yang ditetapkan dalam Rencana Aksi Pembinaan Gizi Masyarakat tahun 2015-2019 adalah pencapaian USI yaitu 95\%. ${ }^{2}$

Kekurangan yodium merupakan salah satu masalah gizi kurang yang masih di hadapi oleh pemerintah Indonesia. Defisiensi gizi ini dapat diderita oleh setiap tahap kehidupan, mulai dari masa prenatal sampai lansia. Defiensi yodium sebelumnya di kenal dengan istilah gondok (perbesaran kelenjar thyroid) yang merupakan salah satu gejala yang timbul akibat kekurangan zat gizi tersebut. Akibat defisiensi yodium saat ini di ketahui tidak hanya pembesaran kelenjar thytoid, tetapi jauh lebih luas. Spekrum akibat defisiensinya sangat luas mulai dari keguguran, lahir mati, cacat bawaan, kretin, dan hipotiroid. ${ }^{3,4}$

Masalah GAKY di masyarakat terkendali jika produksi penduduk dengan EIU $<100 \mu \mathrm{g} / \mathrm{L}$ di bawah $20 \%$ dan cakupan garam beryodium $90 \%$ diikuti dengan tercapainya indicator manajemen. Hasil riskesdas 2010 mendapatkan bahwa proporsi ElU $<100 \mu \mathrm{g} / \mathrm{L}$ sebesar $12,9 \%{ }^{5}$, dan hasil Riskesdas 2013 sebesar 14,9\%. Jadi secara nasional proporsi EIU $<100 \mu \mathrm{g} / \mathrm{L}$ telah berada di bawah 20\%. Sedangkan proporsi rumah tangga konsumsi garam boryodium di aceh dari data riskesdas tahun 2013 adalah yang terendah yaitu 45,7\% data rutin 2013. Target proporsi rumah tangga yang mengkonsumsi garam beryodium pada tahun 2013 adalah sebesar 85\% sedangkan pada tahun 2014 di targetkan sebesar 90\%. ${ }^{6}$ Provinsi Aceh mempunyai tingkat penggunaan garam yodium yang rendah. Hasil pemantauan status gizi dan monitoring gizi tahun 2015, secara Propinsi di Aceh hanya sebesar $57,9 \%$ yang menggunakan garam beryodium, dan Kota Banda Aceh penggunaan garam yang mengandung yodium hanya sebesar $37,6 \%{ }^{7}$

Tinggi rendahnya derajat kesehatan masyarakat sangat dipengaruhi oleh faktor lingkungan, perilaku kesehatan dan pelayanan kesehatan yang semuanya saling berkaitan dan saling mempengaruhi. ${ }^{8}$ Salah satu masalah kesehatan yang serius di Indonesia adalah Gangguan Akibat Kekurangan Iodium (GAKI) karena secara langsung atau tidak langsung berpengaruh pada kualitas fisik dan kualitas non fisik individu dalam masyarakat yaitu intelektualitas dan keterbelakangan mental., ${ }^{4,8}$ Kurangnya intelektual individu sangat mempengaruhi produktifitas secara sosial dan ekonomi yang pada akhirnya mengakibatkan bertambahnya jumlah penduduk yang miskin dan cenderung menjadi beban pembangunan karena ketidakmampuan secara fisik (cacat fisik atau kretin), rendahnya kemampuan kognitif dan juga gangguan perkembangan mental. ${ }^{9}$

Mendorong masyarakat untuk dapat menggunakan garam beriodium pemerintah melakukan berbagai macam upaya antara lain melakukan Komunikasi, Informasi dan Edukasi (KIE) dan mobilisasi sosial GAKI tentang perlunya upaya mengkonsumsi garam beriodium. Upaya yang dilakukan dengan mengoptimalkan penggerakan masyarakat dan kampanye mengkonsumsi garam beriodium, serta dukungan regulasi yang memadai. Salah satu langkah yang cukup strategis untuk menimbulkan motivasi ke arah perbaikan konsumsi garam beriodium adalah melakukan penyuluhan dan pemberdayaan masyarakat, karena dengan masyarakat mempunyai pengetahuan yang baik maka akan dapat meningkatkan pemakaian garam beriodium. ${ }^{10,11}$

Rendahnya pencapaian konsumsi garam beryodium salah satu faktor yaitu ibu rumah tangga yang tidak menggunakan garam beryodium pada masakan mereka. Terdapat kaitan antara ibu rumah tangga dengan konsumsi garam beryodium di rumah tangga, yang menyatakan intervensi yang tepat dilaksanakan untuk meningkatkan konsumsi garam beryodium di tingkat rumah tangga adalah dengan peningkatan peran ibu rumah tangga dalam pendekatan keluarga. ${ }^{4}$ 
Perilaku seseorang dipengaruhi oleh tiga faktor yaitu faktor predisposisi, faktor pendukung, faktor pendorong. Faktor predisposisi yang dimaksud adalah faktor yang mempermudah terjadinya perilaku seseorang seperti pengetahuan, sikap, keyakinan, kepercayaan, tradisi, nilai-nilai dan unsur-unsur lain. ${ }^{12}$ Terkait faktor predisposisi ibu rumah tangga terhadap perilaku dalam mengkonsumsi garam beryodium dalam rumah tangga, menyatakan ada hubungan tingkat pengetahuan ibu rumah tangga tentang GAKY dengan cara menyimpan dan menggunakan garam beyodium. ${ }^{13}$ Selain itu juga menunjukkan bahwa terdapat hubungan signifikan antara sikap terhadap penggunaan garam beryodium dengan kejadian penyakit gndok pada wanita usia subur yang memiliki satu anak, akibat rendahnya konsumsi garam iodium.

Berdasarkan kajian diatas menunjukkan pengetahuan dan sikap serta tindakan merupakan faktor internal dari ibu rumah tangga yang menjadi dasar terjadinya perilaku konsumsi garam beryodium di rumah tangga tersebut. Artikel ini bertujuan untuk mengukur secara spesifik terkait pengetahuan dan sikap serta tindakan ibu rumah tangga dengan garam penggunaan garam beryodium dalam rumah tangga di Kota Banda Aceh.

\section{METODE}

Penelitian ini merupakan penelitian kuantitatif yang menggunakan jenis Quasi Experimental. Sedangkan rancangan menggunakan pendekatan pretest posttest non equivalent group yaitu suatu pendekatan eksperimen yang mengontrol situasi penelitian rancangan sebelum dan sesudah intervensi tanpa menggunakan kelompok kontrol sebagai pembanding eksternal. Jenis dan rancangan penelitian menggunakan subjek penelitian yang terdiri dari dua kelompok yang masing-masing subjek bersifat non-random assignment. ${ }^{14}$ Penelitian ini untuk meningkatkan pengetahuan, sikap, dan tindakan ibu tentang kandungan iodium dalam garam konsumsi rumah tangga melalui pelatihan pemeriksaan garam beryodium pada daerah pesisir serta pegunungan di Kota Banda Aceh dan Aceh Besar.
Sampel merupakan ibu rumah tangga yang mempunyai balita pada daerah terpilih. Perhitungan besar sampel menggunakan persamaan tes hipotesis untuk rata-rata dua kelompok $^{15}$, yang mengacu kepada referensi data Amalia, et al. ${ }^{16}$ Rumus tersebut yaitu sebagai berikut:

$$
n=\frac{2 \sigma^{2}\left(Z_{1-\alpha / 2}+Z_{1-\beta}\right)^{2}}{\left(\mu_{0}-\mu_{a}\right)^{2}}
$$

Keterangan :

$\mathrm{n} \quad=$ Besar Sample (54 ibu balita)

$\sigma^{2} \quad=$ Variansi dari populasi $(92,16)$

$\mu_{0} \quad=$ Nilai rata-rata pada kelompok populasi yang uji $(58,3)$

$\mu_{a}=$ Nilai rata-rata yang diantisipasi terhadap kelompok populasi $(65,0)$

$Z_{1-\alpha / 2}=$ Tingkat Kemaknaan untuk hipotesis dua arah $(5 \%=1,96)$

$Z_{1-\beta}=$ Kekuatan Uji studi yang diinginkan $(95 \%=1,6449)$

Pengambilan sampel dilakukan secara probability sampling dengan teknik random sampling melalui 2 (dua) tahap, yaitu: (1) tahap pertama memilih populasi (ibu-ibu RT yang mempunyai balita) untuk setiap daerah, sehingga dari perhitungan besar sampel diperoleh sebanyak $54 \mathrm{ibu}$, terdiri dari 30 orang dari kelompok pesisir dan 24 dari kelompok pegunungan; dan (2) tahap kedua memilih sampel melalui acak sederhana sebanyak besar sampel pada masing-masing daerah.

Pengumpulan data primer meliputi identitas sampel yang terdiri dari nama, usia, tempat tinggal, pendidikan, pekerjaan, jumlah anak, jumlah balita, pendapatan keluarga, pengetahuan, sikap dan tindakan tentang garam beryodium. Dilakukan secara wawancara menggunakan kuesioner terstruktur yang telah melalui proses uji validitas dan reliabelitas, sedangkan pemeriksaan kandungan garam yodium dilakukan melalui pemberian pelatihan kepada ibu rumah tangga.

Pengolahan data pengetahuan dari 20 butir pertanyaan, yaitu setiap pertanyaan mempunyai 3 (tiga) opsi jawaban dengan dengan nilai " 0 " jika jawaban salah, dan nilai "1" jika jawaban mendekati benar, serta nilai "2" jika jawaban benar. Hasil akhir mempunyai skor minimal 0 dan maksimal 40. Data sikap diolah dari 20 butir 
pertanyaan dan masing-masingmempunyai 4 (empat) opsi jawaban dengan dengan nilai " 0 " jika jawaban sangat tidak setuju (STS), nilai "1" jika tidak setuju (ST), nilai "2" jika setuju (S), dan nilai "3" jika sangat setuju (SS). Hasil akhir mempunyai skor minimal 0 dan maksimal 60. Data tindakan dari 10 pertanyaan mempunyai 3 (tiga) opsi jawaban, yaitu Selalu (S) dengan nilai "2", jawaban Kadang-kadang (K) dengan nilai "1", dan jawaban Tidak Pernah (TP) dengan nilai " 0 ". Hasil akhir mempunyai skor minimal 0 dan maksimal 20. Skoring akhir dari pengetahuan, sikap dan tindakan berupa total skor, nilai minimum, maksimum, rata-rata dan deviasi.

Analisis data dimulai dengan melakukan analisis secara deskriptif, yaitu mendeskripsikan objek melalui data-data pada sampel yang diteliti berdasarkan variabelitasnya. Beberapa statistik yang digunakan pada analisis ini yaitu distribusi frekwensi, minimum, maximum, mean dan deviasi. Pada pengujian pra syarat analisis, datadata pada variabel independen maupun dependen harus berdistribusi normal dan homogen.
Pengujian normalitas data digunakan uji Shaphiro Wilks, hasil menunjukkan bahwa semua data mempunyai distribusi yang normal $(\mathrm{p}>0,05)$. Sedangkan pengujian homogenitas varians tes statistik yang digunakan adalah uji $\mathrm{F}$ (Levene's Test for Equality of Variances) juga menunjukkan kedua kelompok data mempunyai varian yang sama ( $p>0,05)$. Pembuktian hipotesis yang diajukan, maka analisis bivariat terdapat dua bentuk uji statistik yang digunakan yaitu Repeated Measure Anova dan Independent T-Test.

\section{HASIL DAN PEMBAHASAN}

\section{Karakteristik Sampel}

Daerah pesisir dipilih pada daerah pantai di Kota Banda Aceh, sedangkan daerah pegunungan dipilih pada Kabupaten Aceh Besar. Jumlah sampel pada kelompok intervensi pelatihan (daerah pesisir) yaitu 30 orang dan kelompok intervensi melalui ceramah (daerah pegunungan ) yaitu sebanyak 24 orang.

Tabel 1. Distribusi karakteristik subjek penelitian menurut kelompok penelitian di daerah pesisir dan daerah pegunungan

\begin{tabular}{|c|c|c|c|c|c|}
\hline \multirow{3}{*}{ Karakteristik Subjek } & \multicolumn{4}{|c|}{ Kelompok Intervensi } & \multirow{3}{*}{ Nilai $p$} \\
\hline & \multicolumn{2}{|c|}{ Pelatihan } & \multicolumn{2}{|c|}{ Ceramah } & \\
\hline & $\mathrm{n}$ & $\%$ & $\mathrm{n}$ & $\%$ & \\
\hline \multicolumn{6}{|l|}{ Umur } \\
\hline $20-29$ tahun & 11 & 36,7 & 9 & 37,5 & 0,948 \\
\hline $30-39$ tahun & 16 & 53,3 & 12 & 50,0 & \\
\hline $40-49$ tahun & 3 & 10,0 & 3 & 12,3 & \\
\hline \multicolumn{6}{|l|}{ Pendidikan } \\
\hline SD & 3 & 10,0 & 2 & 8,3 & 0,990 \\
\hline SMP & 4 & 13,3 & 4 & 16,7 & \\
\hline SMA & 14 & 46,7 & 11 & 45,8 & \\
\hline Akademi & 6 & 20,0 & 4 & 16,7 & \\
\hline Perguruan Tinggi & 3 & 10,0 & 3 & 12,5 & \\
\hline \multicolumn{6}{|l|}{ Pekerjaan } \\
\hline PNS/BUMN/TNI/ Polri & 5 & 16,7 & 7 & 29,2 & 0,717 \\
\hline Petani/Berkebun & 9 & 30,0 & 7 & 29,2 & \\
\hline Pedagang/Wiraswasta & 7 & 23,3 & 4 & 16,7 & \\
\hline Ibu Rumah Tangga & 9 & 30,0 & 6 & 25,0 & \\
\hline \multicolumn{6}{|l|}{ Pendapatan } \\
\hline Dibawah UMP & 10 & 33,3 & 7 & 29,2 & 0,974 \\
\hline Diatas UMP & 20 & 66,7 & 17 & 70,8 & \\
\hline Total & 30 & 100,0 & 24 & 100,0 & \\
\hline
\end{tabular}


Hasil penelitian (Tabel 1) terhadap karakteristik sampel menurut daerah pesisir (diberikan pelatihan) maupun daerah pegunungan (tidak diberikan pelatihan) meliputi umur, pendidikan, pekerjaan dan pendapatan keluarga tergambarkan bahwa karakteristik sampel baik pada kelompok yang diberikan pelatihan maupun yang diberikan ceramah secara umum hampir menunjukan informasi yang sama. Pada kelompok intervensi pelatihan, umur sampel umumnya 30 - 39 tahun $(53,3 \%)$ dengan pendidikan mayoritas yaitu SMA $(46,7 \%)$, sedangkan pekerjaan lebih banyak bertani/berkebun $(30,0 \%)$, walaupun demikian pendapatan masih banyak diatas UMP $(66,7 \%)$. Begitu juga pada kelompok intervensi ceramah, juga secara umum umur sampel antara 30 - 39 tahun $(50,0 \%)$ serta berpendidikan SMA $(45,8 \%)$, tetapi demikian banyak sampel dalam kelompok tersebut yang bekerja sebagai PNS/BUMN/TNI/Polri (29,2\%) dan bertani/berkebun $(29,2 \%)$, dan searah dengan tingginya pendapatan sampel diatas UMP $(70,8 \%)$.

Kelompok sampel/subjek yang terpilih dilakukan penyesesuai antara kelompok intervensi pelatihan dengan intervensi ceramah, hal ini dilakukan supaya kelompok data benar-benar homogen. Tujuan tersebut untuk menghilangkan pengaruh karakteristik terhadap peningkatan hasil intervensi. Sehingga perlu untuk dilakukan uji komparasi (Chi-Square pada CI:95\%) karakteristik diantara kedua kelompok. Berdasarkan hasil uji komparasi tersebut, bahwa semua variabel atau karakteristik sampel diperoleh nilai $\mathrm{p}$ > 0,05. Dapat disimpulkan bahwa karakteristik umur, pendidikan, pekerjaan dan pendapatan antara kedua kelompok tidak berbeda atau berasal dari karakteristik yang sama sehingga diharapkan tidak terjadinya ketimpangan data dalam penelitian ini.

\section{Gambaran Pengetahuan, Sikap dan Tindakan Ibu tentang Garam Beryodium} Gambaran terhadap sebaran data pengetahuan, sikap dan tindakan ibu tentang garam beryodium pada daerah pesisir dan daerah pegunungan antara sebelum diberikan intervensi maupun satu minggu dan dua minggu setelah intervensi menurut disajikan pada Tabel 2.

Tabel 2. Sebaran data pengetahuan, sikap dan tindakan ibu tentang garam beryodium menurut intervensi pelatihan $(n=30)$ dan kelompok intervensi ceramah $(n=24)$

\begin{tabular}{lccc}
\hline \multirow{2}{*}{$\begin{array}{c}\text { Perilaku (aspek pengetahuan, } \\
\text { sikap, dan tindakan) }\end{array}$} & $\begin{array}{c}\text { Sebelum } \\
\text { intervensi }\end{array}$ & $\begin{array}{c}1 \text { minggu setelah } \\
\text { intervensi }\end{array}$ & $\begin{array}{c}2 \text { minggu setelah } \\
\text { intervensi }\end{array}$ \\
\cline { 2 - 4 } & Mean \pm SD & Mean \pm SD & Mean \pm SD \\
\hline Pengetahuan & & & \\
Intervensi Pelatihan & $21,1 \pm 4,46$ & $26,3 \pm 5,69$ & $27,4 \pm 5,26$ \\
$\quad$ Intervensi Ceramah & $19,3 \pm 3,69$ & $22,0 \pm 4,64$ & $22,6 \pm 5,02$ \\
\hline Sikap & & & \\
Intervensi Pelatihan & $32,2 \pm 8,92$ & $41,4 \pm 10,52$ & $42,5 \pm 10,76$ \\
$\quad$ Intervensi Ceramah & $29,2 \pm 7,28$ & $30,6 \pm 6,79$ & $30,3 \pm 6,29$ \\
\hline Tindakan & & & \\
Intervensi Pelatihan & $12,2 \pm 2,82$ & $16,8 \pm 3,16$ & $18,4 \pm 2,99$ \\
Intervensi Ceramah & $10,7 \pm 3,55$ & $11,5 \pm 3,27$ & $12,7 \pm 2,92$ \\
\hline
\end{tabular}

Secara deskriptif, berdasarkan Tabel 2 dapat dipaparkan bahwa sebaran data hasil penelitian terkait pengetahuan, sikap dan tindakan menurut kelompok intervensi mempunyai kenaikan nilai rerata dari sebelum intervensi sampai 2 minggu setelah intervensi. Selain itu juga bisa tergambarkan secara deskriptif, bahwa data untuk kelompok intervensi pelatihan mempunyai nilai rerata yang lebih tinggi terhadap semua variabel (pengetahuan, sikap dan tindakan) 
daripada dibandingkan kelompok intervensi ceramah. Hasil ini dapat disimpulkan secara deskriptif bahwa, ibu-ibu yang mendapat intervensi pelatihan dan intervensi ceramah mempunyai peningkatan rerata pengetahuan, sikap dan tindakan baik pada minggu pertama maupun pada minggu kedua setelah pelatihan. Walaupun intervensi keduanya meningkatkan rerata pengetahuan, sikap dan tindakan akan tetapi ibu-ibu yang mendapat intervensi pelatihan relatif lebih baik pengetahuan, sikap dan tindakannya dibandingkan ibu-ibu yang mendapat intervensi ceramah setelah dilakukan evaluasi pada minggu pertama dan minggu kedua.

\section{Pengaruh Pelatihan Garam Beryodium terhadap Peningkatan Pengetahuan, Sikap dan Tindakan Ibu}

Asumsi kenormalan serta syarat sperisitas distribusi data telah terpenuhi ( $\mathrm{p}>$ 0,05), maka uji Repeated ANOVA baru bisa digunakan untuk melakukan analisis data dalam penelitian ini. Berikut merupakan hasil analisis data secara analitik yang meliputi pengetahuan, sikap dan tindakan ibu tentang garam beryodium yang dikelompokan menurut kelompok intervensi pelatihan maupun intervensi ceramah, sebagaimana disajikan pada Tabel 3.

\section{Tabel 3. Hasil uji Repeated Anova terkait pengaruh intervensi garam beryodium terhadap peningkatan pengetahuan, sikap dan tindakan ibu}

\begin{tabular}{llcccl}
\hline \multirow{2}{*}{ Intervensi } & \multirow{2}{*}{ Variabel } & \multicolumn{3}{c}{ Rerata \pm SD menurut Waktu (Minggu) } & Nilai $p$ \\
\cline { 3 - 6 } & & Sebelum & Minggu 1 & Minggu 2 & \\
\hline Pelatihan & Pengetahuan & $21,1 \pm 4,46$ & $26,3 \pm 5,69$ & $27,4 \pm 5,26$ & 0,000 \\
& Sikap & $32,2 \pm 8,92$ & $41,4 \pm 10,52$ & $42,5 \pm 10,76$ & 0,000 \\
& Tindakan & $12,2 \pm 2,82$ & $16,8 \pm 3,16$ & $18,4 \pm 2,99$ & 0,000 \\
\hline \multirow{2}{*}{ Ceramah } & Pengetahuan & $19,3 \pm 3,69$ & $21,9 \pm 4,64$ & $22,6 \pm 5,02$ & 0,000 \\
& Sikap & $29,2 \pm 7,28$ & $30,6 \pm 6,79$ & $30,3 \pm 6,29$ & $0,246^{*}$ \\
& Tindakan & $10,8 \pm 3,56$ & $11,5 \pm 3,27$ & $12,8 \pm 2,92$ & 0,002 \\
\hline
\end{tabular}

Ho gagal ditolak pada CI:95\%

Berdasarkan Tabel 3, hasil uji statistik Repeated Anova diperoleh bahwa hampir semua variabel pada setiap waktu (minggu) pengukuran menghasilkan nilai probabilitas ( $\mathrm{p}$-value) adalah 0,000 dan variabel tindakan pada kelompok intervensi ceramah adalah 0,002 (nilai $\mathrm{p}<0,05$ ). Hasil tersebut menunjukan bahwa setidaknya atau minimal terdapat dua waktu (minggu) pengukuran yang nilai rata-rata skor pengetahuan, sikap dan tindakan tentang garam beryodium berbeda secara signifikan pada ibu, baik pada kelompok intervensi pelatihan maupun intervensi ceramah. Selain itu, terdapat variabel sikap pada kelompok intervensi ceramah yang mempunyai nilai $\mathrm{p}=0,246$, sehingga pada CI:95\% variabel sikap ibu tentang garam beryodium tidak menunjukan perbedaan pada setiap pengukurannya $(\mathrm{p}>0,05)$.

Selanjutnya, untuk mengetahui antar waktu (minggu) pengukuran yang mana saling berbeda secara signifikan pada masing-masing variabel menurut kelompok intervensi, maka dilanjutkan dengan Post Hoc Tes: Multiple comparisons Bonferroni. Hasil uji tersebut disajikan pada Tabel 4.

Berdasarkan hasil uji comparisons Bonferroni (Tabel 4) dapat kita lihat bahwa perubahan pengetahuan, sikap dan tindakan ibu tentang garam beryodium pada kelompok intervensi pelatihan adalah, nilai rata-rata pengetahuan ibu dari sebelum dilatih sampai setelah satu minggu dilatih meningkat sebesar $5,2$ ( $p<0,001)$, kemudian meningkat lagi setelah dua minggu dilatih menjadi $6,3(\mathrm{p}<0,001)$ atau terjadi peningkatan dari minggu pertama ke minggu kedua sebesar $1,1(\mathrm{p}<0,05)$. Sedangkan variabel sikap juga mengalami peningkatan signifikan antara sebelum dilatih dengan setelah satu minggu sebesar 9,2 ( $\mathrm{p}<0,001)$, kemudian pada minggu ketiga meningkat sebesar 10,3, dan antara minggu kedua dengan minggu ketiga peningkatan tidak signifikan $(\mathrm{p}>0,05)$. Selanjutnya variabel tindakan, menunjukan bahwa antara sebelum dengan setelah satu 
minggu (minggu 2) dilakukan pelatihan ternyata sangat signifikan terhadap peningkatan tindakan ibu tentang garam beryodium yaitu sebesar 4,7 ( $p<0,001$ ), dan setelah dievaluasi kembali pada minggu ketiga masih terjadi peningkatan yang signifikan terhadap tindakan ibu tentang garam beryodium yaitu $6,3(\mathrm{p}<0,001)$ atau antara minggu kedua dengan minggu ketiga peningkatan terjadi sebesar 1,6 ( $\mathrm{p}<0,05)$. Hasil ini dapat disimpulkan bahwa, intervensi melalui pelatihan tentang garam beryodium pada ibu rumah tangga secara signifikan dapat meningkatkan pengetahuan, sikap dan tindakan setelah waktu seminggu dievaluasi, dan ibu-ibu masih terus memperdalam pengetahuan serta tindakannya terkait penggunaan garam beryodium walaupun sudah tiga minggu berjalan.

Tabel 4. Hasil uji Post Hoc terkait pengaruh intervensi garam beryodium terhadap peningkatan pengetahuan, sikap dan tindakan ibu menurut waktu (minggu)

\begin{tabular}{|c|c|c|c|}
\hline $\begin{array}{l}\text { Kelompok } \\
\text { Intervensi }\end{array}$ & $\begin{array}{l}\text { Peningkatan skor Variabel } \\
\text { menurut waktu }\end{array}$ & $\begin{array}{l}\text { Perbedaan rerata } \\
\text { skor (CI:95\%) }\end{array}$ & Nilai $p$ \\
\hline \multirow[t]{3}{*}{$\begin{array}{l}\text { Intervensi melalui } \\
\text { Pelatihan (daerah } \\
\text { pesisir) }\end{array}$} & $\begin{array}{l}\text { Pengetahuan: } \\
\text { Sebelum - Minggu } 2 \\
\text { Sebelum - Minggu } 3 \\
\text { Minggu 2 - Minggu } 3\end{array}$ & $\begin{array}{l}-5,2(-6,3 \mathrm{~s} / \mathrm{d}-4,0) \\
-6,3(-7,6 \mathrm{~s} / \mathrm{d}-5,1) \\
-1,1(-2,0 \mathrm{~s} / \mathrm{d}-0,2)\end{array}$ & $\begin{array}{l}0,000 \\
0,000 \\
0,009\end{array}$ \\
\hline & $\begin{array}{l}\text { Sikap: } \\
\text { Sebelum - Minggu } 2 \\
\text { Sebelum - Minggu } 3 \\
\text { Minggu 2 - Minggu } 3\end{array}$ & $\begin{array}{l}-9,2(-11,3 \mathrm{~s} / \mathrm{d}-6,9) \\
-10,3(-12,5 \mathrm{~s} / \mathrm{d}-8,0) \\
-1,1(-2,4 \mathrm{~s} / \mathrm{d}-0,2)\end{array}$ & $\begin{array}{l}0,000 \\
0,000 \\
0,139^{*}\end{array}$ \\
\hline & $\begin{array}{l}\text { Tindakan: } \\
\text { Sebelum - Minggu } 2 \\
\text { Sebelum - Minggu } 3 \\
\text { Minggu 2 - Minggu } 3\end{array}$ & $\begin{array}{l}-4,7(-5,7 \mathrm{~s} / \mathrm{d}-3,7) \\
-6,3(-7,5 \mathrm{~s} / \mathrm{d}-4,9) \\
-1,6(-2,8 \mathrm{~s} / \mathrm{d}-0,4)\end{array}$ & $\begin{array}{l}0,000 \\
0,000 \\
0,008\end{array}$ \\
\hline \multirow[t]{3}{*}{$\begin{array}{l}\text { Intervensi melalui } \\
\text { Ceramah (daerah } \\
\text { pegunungan) }\end{array}$} & $\begin{array}{l}\text { Pengetahuan: } \\
\text { Sebelum - Minggu } 2 \\
\text { Sebelum - Minggu } 3 \\
\text { Minggu 2 - Minggu } 3\end{array}$ & $\begin{array}{l}-2,7(-3,9 \mathrm{~s} / \mathrm{d}-1,4) \\
-3,4(-5,5 \mathrm{~s} / \mathrm{d}-1,2) \\
-0,7(-2,5 \mathrm{~s} / \mathrm{d} 1,2)\end{array}$ & $\begin{array}{l}0,000 \\
0,001 \\
1,000^{*}\end{array}$ \\
\hline & $\begin{array}{l}\text { Sikap: } \\
\text { Sebelum - Minggu } 2 \\
\text { Sebelum - Minggu } 3 \\
\text { Minggu 2 - Minggu } 3\end{array}$ & $\begin{array}{r}-1,4(-3,5 \text { s/d } 0,7) \\
-1,1(-3,8 \text { s/d } 1,6) \\
0,3(-1,7 \text { s/d } \quad 2,3)\end{array}$ & $\begin{array}{l}0,275^{*} \\
0,878^{*} \\
1,000^{*}\end{array}$ \\
\hline & $\begin{array}{l}\text { Tindakan: } \\
\text { Sebelum - Minggu } 2 \\
\text { Sebelum - Minggu } 3 \\
\text { Minggu 2 - Minggu } 3\end{array}$ & $\begin{array}{l}-0,8(-1,8 \mathrm{~s} / \mathrm{d} \quad 0,3) \\
-2,0(-3,3 \mathrm{~s} / \mathrm{d}-0,7) \\
-1,3(-2,2 \mathrm{~s} / \mathrm{d}-0,3)\end{array}$ & $\begin{array}{l}0,221^{*} \\
0,001 \\
0,006\end{array}$ \\
\hline
\end{tabular}

" Tidak signifikan pada CI: $95 \%$

Kelompok intervensi melalui ceramah tentang garam beryodium yang diberikan kepada ibu rumah tangga, hanya bisa meningkatkan pengetahuan antara sebelum dengan setelah satu minggu (minggu kedua) diberikan pelatihan yaitu sebesar 2,7 ( $\mathrm{p}<$ $0,001)$, dan sampai minggu ketiga meningkat lagi sebesar $3,4(\mathrm{p}<0,05)$ serta tidak terjadi peningkatan antara minggu kedua dengan minggu ketiga $(p>0,05)$. Intervensi melalui ceramah, ternyata belum mampu merubah sikap ibu tentang garam beryodium baik antara sebelum dengan setelah dua minggu dan tiga minggu maupun antara minggu kedua dengan minggu ketiga $(\mathrm{p}>0,05)$. Sedangkan variabel tindakan, walaupun belum mampu merupaka tindakan ibu antara sebelum dengan setelah dua minggu pelatihan $(\mathrm{p}>0,05)$, tetapi sangat 
signifikan terjadi peningkatan tindakan antara sebelum dengan setelah minggu ketiga sebesar $2,0$ ( $\mathrm{p}<0,05)$, dan antara minggu kedua dengan minggu ketiga sebesar 1,3 ( $<<0,05)$. Hasil tersebut bisa disimpulkan bahwa, intervensi melalui ceramah tentang garam beryodium kepada ibu rumah tangga hanya mampu meningkatkan (merubah) pengetahuan ibu dalam waktu singkat, sedangkan sikap belum mampu untuk dirubah. Walaupun demikian, intervensi ceramah sangat bagus untuk merubah pola atau tindakan ibu pada kurun waktu yang lama.

Hasil penelitian menyebutkan bahwa, intervensi yang diberikan kepada ibu-ibu melalui suatu pendekatan pelatiah tentang garam beryodium secara signifikan dapat meningkatkan pengetahuan, sikap dan tindakan ibu di Kota Banda Aceh dan Kabupaten Aceh Besar, serta mempunyai penerapan hasil dari pelatihan tersebut sangat baik. Hal ini berarti, meningkatnya pengetahuan, sikap dan tindakan ibu tidak saja berubah pada waktu sementara tetapi memungkinkan untuk waktu yang relatif lebih lama. Begitu juga dengan intervensi melalui ceramah juga dapat meningkatkan pengetahuan serta tindakan, tetapi belum mampu meningkatkan sikap ibu tentang garam beryodium, selain itu intervensi melalui ceramah penerapa untuk pengetahuan dan tindakan kurang baik. Artinya, melalui intervensi ceramah pengetahuan ibu dapat berubah hanya bersifat sementara tetapi tidak untuk waktu yang lebih lama, sebaliknya tindakan ibu dalam waktu singkat susah berubah tetapi cenderung lebih baik perubahan tindakan apabila diikuti selama tiga minggu.

Hasil penelitian ini searah dengan beberapa hasil penelitian lain, seperti penelitian Permatasari bahwa pengetahuan dan sikap serta praktik tentang gizi berpengaruh terhadap penggunaan garam beryodium serta menunjukan juga bahwa pengaruh tersebut bersifat positif ${ }^{16}$, selain itu pengetahuan yang baik berhubungan dengan penanganan garam beryodium seperti penyimpanan, penggunaan, mutu garam beryodium ${ }^{17}$. Menurut Mariza ${ }^{18}$, pengetahuan dan sikap serta tindakan yang dimiliki ibu dapat mempengaruhi penggunaan garam beryodium di rumah tangga, karena ibu mendapatkan informasi tentang manfaat garam beryodium baik secara langsung dari tenaga kesehatan, keluarga atau teman, maupun tidak langsung. Aspek tersebut mendorong ibu untuk menggunakan garam beryodium dari pada menggunakan garam kiloan atau garam biasa yang bisa di dapat dipasar dengan harga yang lebih murah, namun dengan pengetahuan tentang pentingnya mengkonsumsi garam beryodium banyak ibu yang memilih menggunakan garam beryodium. ${ }^{19,20}$

Peningkatan pengetahuan seseorang tidak hanya diperoleh dengan cara membaca, tetapi untuk meningkatkan pemahaman dan persepsi mereka lebih baik melalui suatu bentuk kegiatan pelatihan. Suatu bentuk pelatihan dan penyegaran yang dilakukan secara berkelanjutan harus tetap diperlukan karena terdapatnya pergantian jabatan dalam pekerjaan atau perubahan uraian kerja serta masih terbatasnya pemahaman dan keterampilan masyarakat. ${ }^{21}$

Pelaksanaan pelatihan dan penerapan ilmu tentang pemeriksaan dan penanganan garam beryodium di Kota Banda Aceh dan Kabupaten Aceh Besar, secara keseluruhan mempunyai pengaruh yang sangat baik terhadap perubahan pengetahuan, sikap dan tindakan ibu serta secara signifikan berpengaruh dalam meningkatkan nilai-nilai pengetahuan, sikap dan tindakan ibu tentang garam beryodium. Walaupun pada intervensi ceramah, sikap belum signifikan dapat ditingkatkan.

\section{Perbedaan Peningkatan Pengetahuan, Sikap dan Tindakan Ibu setelah Intervensi Pelatihan dengan Intervensi Ceramah}

Perbedaan peningkatan pengetahuan, sikap dan tindakan ibu setelah dilakukan intervensi dapat dikur melalui perbandingan atau efektivitas diatara kedua kelompok yang bertujuan untuk mengkomparasi apakah penerapan pelatihan pada daerah pesisir lebih baik dibandingkan penerapan ceramah pada daerah pegunungan oleh masing-masing ibu rumah tangga tentang penggunaan garam 
beryodium. Pengukuran tersebut dimulai sebelum intervensi, minggu kedua setelah intervensi bahkan sampai penerapannya sampai minggu ketiga. Selanjutnya, untuk mengetahui hasil efektivitas tersebut, digunakan uji statistik
Independent T-Test. Berikut hasil analisis data yang meliputi pengetahuan, sikap dan tindakan ibu tentang garam beryodium menurut kelompok pelatihan (daerah pesisir) dan kelompok ceramah (daerah pegunungan).

Tabel 5. Hasil uji komparasi terhadap pengetahuan, sikap dan tindakan ibu tentang garam beryodium menurut daerah pesisir $(n=30)$ dengan daerah pegunungan $(n=24)$ di Kota Banda Aceh dan Kabupaten Aceh Besar

\begin{tabular}{lcccccc}
\hline \multirow{2}{*}{$\begin{array}{c}\text { Perilaku Ibu } \\
\text { menurut intervensi }\end{array}$} & \multicolumn{5}{c}{ Intervensi Kandungan Iodium dalam Garam } \\
\cline { 2 - 7 } & \multicolumn{2}{c}{ Sebelum intervensi } & \multicolumn{2}{c}{$\begin{array}{c}\text { Setelah minggu } 2 \\
\text { intervensi }\end{array}$} & $\begin{array}{c}\text { Setelah minggu } 3 \\
\text { intervensi }\end{array}$ \\
\cline { 2 - 7 } & Rerata \pm SD & Nilai $p$ & Rerata \pm SD & Nilai $p$ & Rerata \pm SD Nilai $p$ \\
\hline $\begin{array}{c}\text { Pengetahuan } \\
\text { Pelatihan }\end{array}$ & $21,1 \pm 4,5$ & $0,108^{*}$ & $26,3 \pm 5,7$ & 0,004 & $27,4 \pm 5,3$ & 0,001 \\
Ceramah & $19,3 \pm 3,7$ & & $21,2 \pm 4,6$ & & $22,6 \pm 5,0$ & \\
\hline Sikap & & & & & & \\
Pelatihan & $32,2 \pm 8,9$ & $0,190^{*}$ & $41,4 \pm 10,5$ & 0,000 & $42,5 \pm 10,8$ & 0,000 \\
Ceramah & $29,2 \pm 7,3$ & & $30,6 \pm 6,9$ & & $30,3 \pm 6,3$ & \\
\hline Tindakan & $12,2 \pm 2,8$ & $0,108^{*}$ & $16,8 \pm 3,2$ & 0,000 & $18,4 \pm 2,9$ & 0,000 \\
Pelatihan & $10,8 \pm 3,6$ & & $11,5 \pm 3,3$ & & $12,8 \pm 2,9$ & \\
Ceramah & & & & & & \\
\hline
\end{tabular}

${ }^{*}$ Tidak signifikan pada CI: $95 \%$

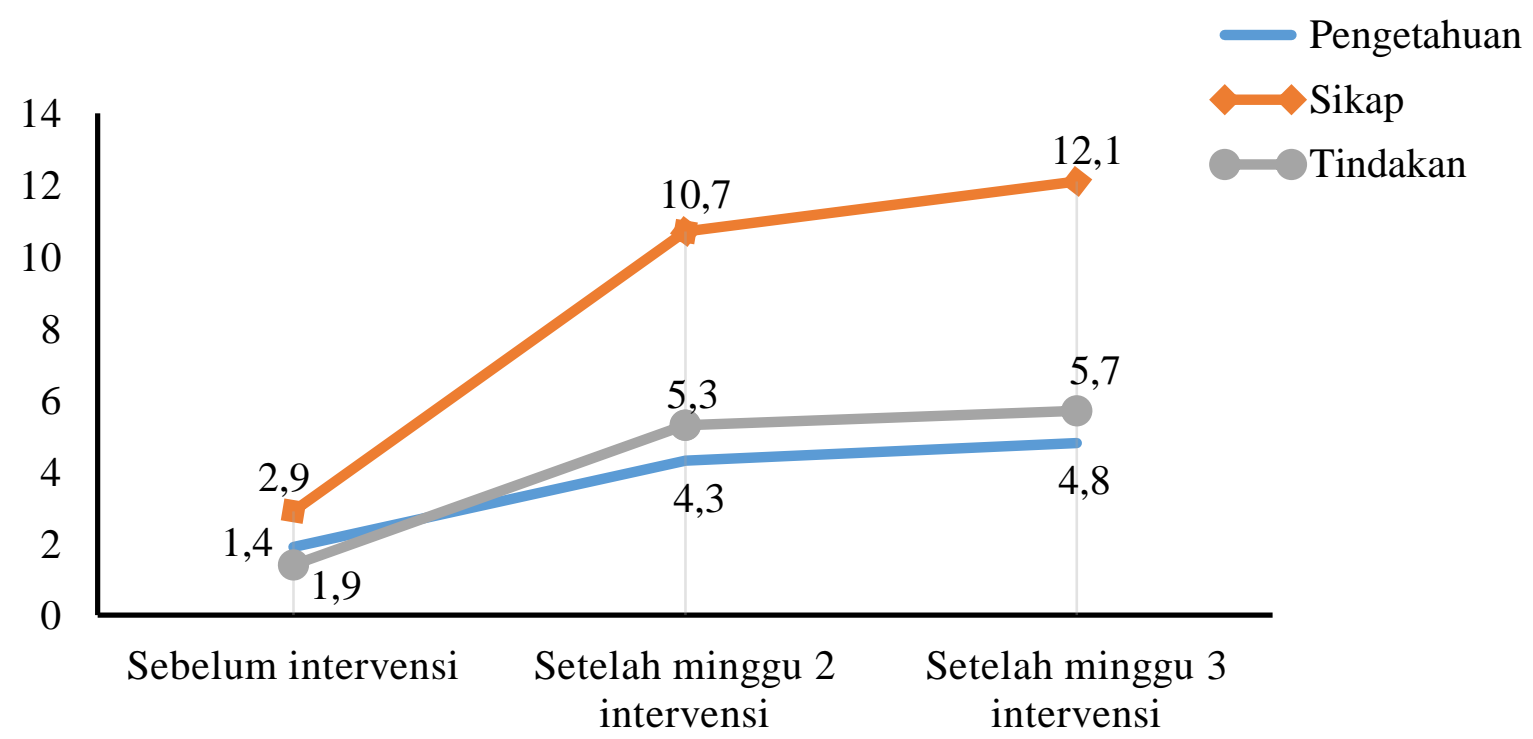

Gambar 1. Grafik perubahan dan peningkatan pengetahuan, sikap dan tindakan antara intervensi pelatihan dengan ceramah menurut waktu (minggu)

Hasil penelitian (Tabel 5) dapat memastikan bahwa pengetahuan, sikap dan tindakan ibu tentang garam beryodium sebelum diberikan intervensi antara daerah pesisir dengan daerah pegunungan tidak menunjukan perbedaan bermakna $(\mathrm{p}>0,05)$ atau dapat disimpulkan bahwa sebelum diberikan intervensi, ibu-ibu rumah tangga yang tinggal didaerah pesisir mempunyai pengetahuan, sikap serta tindakan relatif sama dengan ibu yang tinggal didaerah pegunungan pada wilayah Kota Banda Aceh dan Kabupaten Aceh Besar. Setelah dilakukan 
intervensi yaitu berupa pelatihan dan ceramah tentang garam beryodium, hasil evaluasi (setelah minggu 2) menunjukan bahwa pada ibu yang mendapat intervensi yaitu pelatihan tentang garam beryodium mempunyai rerata pengetahuan, sikap dan tindakan yang lebih besar dibandingkan dengan ibu yang mendapat intervensi ceramah, tentunya ini menunjukan perbedaan signifikan diantara kedua kelompok $(\mathrm{p}<0,05)$. Selanjutnya, hasil evaluasi kedua (setelah minggu 3) ternyata juga menunjukan bahwa ibu yang mendapat pelatihan tentang garam beryodium semakin besar nilai pengetahuan, sikap dan tindakan mereka bila dibandingkan dengan ibu yang mendapat ceramah, serta secara signifikan terdapat perbedaan diantara kedua kelompok $(\mathrm{p}<0,05)$. Oleh karena itu, pelatihan tentang garam beryodium sangat baik dalam meningkatkan pengetahuan, sikap dan tindakan ibu dibandingkan intervensi melalui ceramah.

Gambar 1 memberikan informasi secara lebih jelas tentang perbedaan kedua jenis intervensi dalam merubah pengetahuan, sikap, tindakan serta untuk melihat laju peningkatan nilai pada ketiga variabel menurut jenis intervensi disajikan pada gambar berikut ini. Hasil tersebut menunjukkan bahwa intervensi melalui pelatihan sangat baik dalam merubah sikap dan tindakan serta pengetahuan ibu tentang garam yodium dalam rumah tangga mereka dibandingkan intervensi melalui ceramah. Selain itu terdapat peningkatan positif pada kedua jenis intervensi, tetapi intervensi melalui pelatihan mempunyai peningkatan yang lebih baik dibandingkan intervensi melalui ceramah pada ibu rumah tangga di wilayah Kota Banda Aceh dan Kabupaten Aceh Besar.

Penggunaan metode yang tepat dalam suatu intervensi sangat mendukung hasil suatu tujuan. Menilai efektivitas metode serta penerapannya digunakan dua pendekatan model yaitu intervensi melalui pelatihan dibandingkan dengan intervensi melalui ceramah, para peserta dibagi menurut daerah asal yaitu daerah pesisir dan pegunungan. Menurut Al Rahmad et $\mathrm{al}^{15}$, bahwa penerapan yang efektif dari sebuah pelaksanaan pelatihan membutuhkan penggunaan rancangan pelatihan, melalui persiapan dan pertimbangan beberapa konsep seperti model pembelajaran, motivasi belajar, efektifitas diri dan beberapa pendekatan lainnya.

Hasil penelitian menunjukan bahwa pelatihan tentang garam beryodium sangat baik dalam meningkatkan pengetahuan, sikap dan tindakan ibu dibandingkan intervensi melalui ceramah. Menggunakan intervensi melalui pelatihan setelah minggu kedua dan minggu ketiga masih sangat memungkinkan untuk perubahan sikap, tindakan serta pengetahuan ibu tentang garam yodium dalam rumah tangga.

Beberapa hasil penelitian yang mendukung, seperti penelitian Al Rahmad et $\mathrm{al}^{15}$, bahwa sebagai suatu institusi kesehatan sangat penting memberikan pendidikan dan pelatihan dalam mencapai tujuannya untuk menghasilkan tenaga kerja yang berkualitas serta terampil. Pendidikan dan pelatihan tenaga kerja khususnya bidang kesehatan merupakan suatu proses dalam meningkatkan pengetahuan, sikap dan keterampilan terhadap hal-hal yang sifatnya baru maupun proses penyegaran yang pada akhirnya masalah ini akan menjadi salah satu faktor sukses pencapaian tujuan institusi. Kemampuan generalisasi serta tingkat keefektivitasan pelatihan berbasis teknologi menjadi sangat penting dalam bidangnya karena sistem tersebut merupakan suatu tool dalam mendukung proses pelayanan kesehatan, selain itu faktor organisasi sangat mempengaruhi pencapaian tingkat derajat kesehatan masyarakat. ${ }^{11,22}$

Peningkatan kapasitas dan kemampuan serta proses penguatan manajemen yang baik pada tenaga kerja akan sangat membantu dalam meningkatkan cakupan pelayanan kesehatan serta didukung oleh penggunaan fasilitas yang baik. ${ }^{23}$ Sebaliknya, melemahnya struktur organisasi, proses yang kurang baik dan kurangnya pengetahuan serta rendahnya keterampilan menjadi faktor dasar yang menghambatnya pemberian pelayanan kesehatan kepada masyarakat. ${ }^{24}$ Sumber daya manusia sangat mempengaruhi program kerja, yang mana bahwa rendahnya kualitas sumber daya manusia menjadi faktor penghambat berhasilnya program pemantauan dan pertumbuhan balita dan rendahnya cakupan 
program kesehatan masyarakat pada
umumnya. $^{25}$

\section{KESIMPULAN}

Intervensi melalui pelatihan tentang garam beryodium pada ibu rumah tangga secara signifikan dapat meningkatkan pengetahuan, sikap dan tindakan setelah waktu seminggu dievaluasi, dan ibu-ibu masih terus memperdalam pengetahuan serta tindakannya terkait penggunaan garam beryodium walaupun sudah tiga minggu berjalan. Sedangkan intervensi melalui ceramah hanya mampu meningkatkan (merubah) pengetahuan ibu dalam waktu singkat, sedangkan sikap belum mampu untuk dirubah. Walaupun demikian, intervensi ceramah bagus untuk merubah tindakan ibu pada kurun waktu yang lama.

Pelatihan tentang garam beryodium sangat baik dalam meningkatkan pengetahuan, sikap dan tindakan ibu dibandingkan intervensi melalui ceramah di wilayah Kota Banda Aceh dan Kabupaten Aceh Besar. Intervensi melalui pelatihan sangat baik dalam merubah sikap dan tindakan serta pengetahuan ibu tentang garam yodium dalam rumah tangga mereka dibandingkan intervensi melalui ceramah. Selain itu terdapat peningkatan positif pada kedua jenis intervensi, tetapi intervensi melalui pelatihan mempunyai peningkatan yang lebih baik dibandingkan intervensi melalui ceramah pada ibu rumah tangga.

Saran, sebagai tenaga gizi dan kesehatan maka ahli gizi perlu melakukan penyuluhan gizi tentang yodium serta pelatihan kepada ibu tentang pemeriksaan garam beryodium secara sederhana, karena masih banyak rumah tangga yang belum mengetahui yodium pada kesemua desa. Perlu adanya pemantauan dan pengawasan yang khusus oleh pemerintah melalui dinas kesehatan kabupaten terkait klaim pada kemasan garam beryodium yang mencantumkan garam dengan kadar yodium $\geq$ $30 \mathrm{ppm}$ padahal ketika dilakukan pengujian kadar yodiumnya tidak sampai $30 \mathrm{ppm}$. Selain itu diperlukan penelitian lebih lanjut mengenai cara penyimpanan garam rumah tangga dan penelitian tentang menghitung berapa besar jumlah kehilangan yodium pada saat pemasakan pada pangan sumber yodium, terutama pada wilayah pesisir yang berada di Kota Banda Aceh.

\section{DAFTAR PUSTAKA}

1. Darmawan NI, Darmawan ES. Analisis Demand dan Supply Konsumsi Garam Beryodium Tingkat Rumah Tangga. Kesmas: National Public Health Journal. 2012;6(6):273-276.

2. Bappenas. Rencana Pembangunan Jangka Menengah Nasional 2015-2019. In: 1st ed. Jakarta: Nasional, Kementerian Perencanaan Pembangunan Nasional/Badan Perencanaan Pembangunan; 2014:6-74.

3. Hariyanti W. Faktor-faktor yang mempengaruhi kejadian GAKY pada anak usia sekolah dasar di Kecamatan Kendal Kabupaten Ngawi. Jurnal Tata Boga. 2013;2(1):150-158.

4. Nadimin N. Hubungan Tingkat Pendidikan Dengan Penggunaan Garam Beryodium Tingkat Rumah Tangga Di Sulawesi Selatan. Media Kesehatan Masyarakat Indonesia. 2016;11(4):235-240.

5. Balitbangkes. Riset Kesehatan Dasar (RISKESDAS) Tahun 2010. Jakarta: Badan Penelitian dan Pengembangan Kesehatan Kementerian Kesehatan RI; 2010. www.riskesdas.litbang.go.iddownload TabelRiskesdas2010.pdf.

6. Balitbangkes. Riset Kesehatan Dasar 2013. Pertama. Jakarta: Badan Penelitian dan Pengembangan Kesehatan.; 2013. doi:arXiv:1011.1669v3.

7. Dinas Kesehatan Aceh, Jurusan Gizi. Laporan Manajemen Data Survey Pemantauan Status Gizi Provinsi Aceh Tahun 2016. Banda Aceh; 2016.

8. Al-Rahmad AH, Astika RY. Penggunaan Garam Beryodium Dan Asupan Protein Terhadap Pencapaian Prestasi Murid SDN 5 Kota Banda Aceh. Aceh Nutrition Journal. 2016;1(1):52-58.

doi:http://dx.doi.org/10.30867/action.v1i1.4 2.

9. Balai Litbang GAKI. Rencana Aksi Kegiatan 2015-2019. Magelang; 2014. 
https://www.balitbangkesmagelang.litbang. kemkes.go.id/assets/uploads/files/5a995rencana-aksi-2015-2019.pdf.

10. Hadisuyitno J. The Effect of Lecturing with Booklet Media towards on Knowledge of Posyandu Cadres. JURNAL ILKES (Jurnal Ilmiah Ilmu Kesehatan). 2017;1(6):304309.

11. Guess K, Malek L, Anderson A, Makrides M, Zhou SJ. Knowledge and practices regarding iodine supplementation: A national survey of healthcare providers. Women and Birth. 2017;30(1):e56-e60.

12. Sutiah S, Prameswari GN, Handayani OWK. Faktor yang berhubungan dengan penggunaan garam beriodium tingkat rumah tangga. Journal of Health Education. 2017;2(2):179-184.

13. Astutik VY. Tingkat Pengetahuan, Pola Kebiasaan Lingkungan Hidup Berhubungan Dengan Motivasi Ibu Dalam Memilih Kondisi Garam. Care: Jurnal Ilmiah Ilmu Kesehatan. 2017;5(2):220-230.

14. Creswell JW. Research Design: Pendekatan Kualitatif, Kuantitatif, Dan Campuran. Yogyakarta: Andi Offset; 2010.

15. AL Rahmad AH, Sudargo T, Lazuardi L. The Effectiveness Of WHO Anthro Growth Standard Training On The Data Quality Of Underfive Children's Nutritional Status. Journal of Information Systems for Public Health. 2013; Vol: 1(No: 1):21-26.

16. Amalia L, Permatasari II, Khomsan A, Riyadi H, Herawati T, Nurdiani R. Pengetahuan, sikap, dan praktek gizi ibu terkait iodium dan pemilihan jenis garam rumah tangga di Wilayah Pegunungan Cianjur. Jurnal Gizi dan Pangan. 2015;10(2):133-140.

17. Setiarini EA, Jazilah J, Waryana W. Tingkat Pengetahuan GAKY Dengan Penanganan Garam Beryodium Oleh Ibu Rumah Tangga Di Desa Belah, Kecamatan Donorojo, Kabupaten Pacitan. Media Gizi Mikro Indonesia. 2010;1(2):47-54.

18. Mariza. Analisis Faktor-Faktor yang Berhubungan dengan Penggunaan Garam
Beryodium di Rumah Tangga. 2015.

19. Al Rahmad AH, Almunadia A. Pemanfaatan Media Flipchart dalam Meningkatkan Pengetahuan Ibu Tentang Konsumsi Sayur dan Buah. Jurnal Kedokteran Syiah Kuala. 2017;17(3):140-146. doi:https://doi.org/10.24815/jks.v17i3.9062.

20. Fadjri TK. Pengaruh Pelatihan Pemberian Makan Pada Bayi dan Anak (PMBA) Terhadap Keterampilan Konseling dan Motivasi Bidan Desa. AcTion: Aceh Nutrition Journal. 2017;2(2):97-102. doi:http://dx.doi.org/10.30867/action.v2i2.6 1.

21. Rahmad AHAL. Efektivitas Penggunaan Standar Pertumbuhan WHO Anthro Terhadap Kualitas Dan Informasi Data Status Gizi Balita. Journal of Information Systems for Public Health. 2016;1(1):39-46.

22. Chaudhry B, Wang J, Wu S, Maglione M, Mojica W, Roth E, Morton SC, Shekelle PG. Systematic Review: Impact of Health Information Technology on Quality, Efficiency, and Costs of Medical Care. Annals of Internal Medicine. 2006;144(10):742-752.

http://www.annals.org/content/144/10/742. short.

23. Shrimpton R, du Plessis LM, Delisle H, Blaney S, Atwood SJ, Sanders D, Margetts B, Hughes R. Public health nutrition capacity: assuring the quality of workforce preparation for scaling up nutrition programmes. Public health nutrition. 2016;19(11):2090-2100.

24. Esmail LC, Cohen-Kohler JC, Djibuti M. Human Resource Management in the Georgian National Immunization Program: a Baseline Assessment. Human Resources for Health. 2007;5:20. http://www.pubmedcentral.nih.gov/articlere nder.fcgi? artid $=1950878 \&$ tool=pmcentrez \&rendertype $=$ abstract.

25. Roy R, Chaturvedi M, Agrawal D, Ali H. Household use of iodized salt in rural area. Journal of family medicine and primary care. 2016;5(1):77. 